\title{
Control of Red Elm Bark Weevil (Magdalis armicollis) in American Elm (UImus americana) by Trunk Injection of Azadirachtin
}

\author{
Michael Booth and Mark Goettel
}

\begin{abstract}
Trunk injection of azadirachtin into elm trees (Ulmus americana) using the Ecoject ${ }^{\mathrm{TM}}$ Microinjection System to reduce emergence numbers of red elm bark weevil (Magdalis armicollis) was evaluated. Twelve mature trees were each injected with TreeAzin ${ }^{\mathrm{TM}}$ in early August 2010 at a rate of $16 \mathrm{ml}$ per $15.2 \mathrm{~cm}$ trunk circumference at breast height. The following year, weevil activity was monitored at weekly intervals for four weeks using sticky traps placed in the canopies. There was a significant reduction of 55\%-60\% in weevil activity in early summer in the treated tree canopies as compared to the control, suggesting that this method may be an effective management tool for this pest.

Key Words. American elm; Azadirachta indica; Ecoject ${ }^{\text {TM }}$ Microinjection System; Magdalis armicollis; Neem; Red Elm Bark Weevil; Sticky Trap Sampling; TreeAzin ${ }^{\mathrm{TM}}$; Trunk Injection; Ulmus americana.
\end{abstract}

Populations of mature American elms (Ulmus americana), a highly prized ornamental tree on the Great Plains, are in decline, thus increasing their perceived value and need for protection. The red elm bark weevil (REBW) (Magdalis armicollis) is becoming a serious pest of elms. REBW eggs are laid beneath the bark where larvae and pupae develop. Populations have a tendency to increase in years with warm summers (M. Booth unpublished observations, 1986-2007) and may increase under drought stress (Saunders et al. 2004). The larvae cause damage by feeding and tunneling along the cambium/xylem interface, which interrupts vascular flow and causes dieback of twigs and branches. Because the insect develops beneath the bark, it is very difficult to control using conventional pesticide application methods.

Conventional insect control methods, such as foliar spraying, drench application, banding, or paint-on applications (Doughty et al. 1992), and soil injection have been shown to be effective means of insect control in urban trees, though off-target movement of pesticides may pose risks to non-target organisms, humans, soil, and water. Trunk injection of insecticides targets the pests directly within the trees and has been shown to be an effective means of controlling insect pests of trees and shrubs (Marion et al. 1990; Doccola et al. 2003; Booth and Johnson 2009). Previous tests by the Canadian Forest Service and at the Lethbridge Research Centre (Booth and Johnson 2009) showed potential effectiveness of acephate for control of REBW applied with the Ecoject ${ }^{\mathrm{TM}}$ Microinjection System, developed by BioForest Technologies Inc. (Sault Ste. Marie, Ontario, Canada). The Ecoject injection tool pressurizes small plastic vials that inject small amounts of insecticide into the tree through holes drilled into the tree.

Azadirachtin, extracted from the neem tree (Azadirachta indica), is known to possess systemic activity against several defoliating and leaf-mining insects when injected into trees (Helson et al. 2007). It is registered in the United States as $\operatorname{TreeAzin}^{\mathrm{TM}}$ for use against the emerald ash borer and other foliar-feeding tree pests (EPA Reg. No 82996-1). Researchers evaluated trunk injection of azadirachtin into elm trees using the Ecoject Microinjection System as a means to reduce emergence numbers of the REBW at the Lethbridge Research Centre.

\section{METHODS AND MATERIALS}

\section{Experimental Design}

The experimental units were 24 mature trees, part of a row planting. These trees are on federally owned and managed property near Hwy \#3, east of Lethbridge, Alberta, Canada. Twelve trees were treated, and 12 acted as controls. The experimental design consisted of four treatment trees followed by four control trees followed by four treatment trees and so on, creating three treatment groups of four trees each and three control groups of four trees each. Trunk circumference at breast height of the 24 trees ranged between $109 \mathrm{~cm}$ to $218 \mathrm{~cm}($ mean $=156 \mathrm{~cm})$.

\section{Injection Treatment}

The target application rate was $16 \mathrm{ml}$ of TreeAzin Systemic Insecticide (5\% azadirachtin; BioForest Technologies, Sault Ste. Marie, $\mathrm{ON}) / 15 \mathrm{~cm}$ trunk circumference at breast height. Trees were measured and assigned a number of injectors based on tree size: two, $8 \mathrm{ml}$ injectors per $15 \mathrm{~cm}$ of trunk circumference. The number of canisters used per tree ranged from 14 to 28 . The canisters were pressurized using the Ecoject Microinjection System and inserted into $5.6 \mathrm{~mm}$ holes (2-8 $\mathrm{ml}$ canisters/hole) drilled near the base of the tree, $1.3-1.9 \mathrm{~cm}$ deep, to the cambium. The injector pressure 
was approximately $0.38 \mathrm{MPa}$ at the start of the loading stroke and $0.45 \mathrm{MPa}$ at the end of the stroke. Each injector delivered the entire contents into the tree within 10 to 15 seconds. Injection holes were then filled with silicone sealant. Injection was conducted between 8:00 a.m. and 12:00 noon on August 4 and 5, 2010. Conditions were as follows: August 4: at start $13^{\circ} \mathrm{C}, \mathrm{RH} 89 \%$, wind 4 $\mathrm{km} / \mathrm{h}$; at end $20^{\circ} \mathrm{C}$, RH $53 \%$, wind $4 \mathrm{~km} / \mathrm{h}$; Aug 5: at start $15^{\circ} \mathrm{C}$, $\mathrm{RH} 86 \%$, wind $4 \mathrm{~km} / \mathrm{h}$; at end $22^{\circ} \mathrm{C}$, RH $54 \%$, wind $13 \mathrm{~km} / \mathrm{h}$.

\section{Sampling}

\section{Insects}

Five yellow "Tanglefoot" (Contech Industries, Delta, British Columbia, Canada) sticky traps $10 \mathrm{~cm} \times 15 \mathrm{~cm}$ were established in each tree in the year following insecticide applications. A total of 120 traps were hung from branches 10 to $12 \mathrm{~m}$ above ground level at the beginning of each sampling period using a man lift, then removed and returned to the laboratory for counting the number of adult REBW. Collection and replacement of traps was conducted until populations generally declined. Samples were taken one, two, three, and four weeks following detection of REBW. Traps were established in trees June 29-30, 2011, and sampling commenced between July 6 and 7, 2011.

\section{Statistical Analysis}

Data were analyzed using three reps for each treatment after calculating the means over the four subsamples. In addition, data were analyzed using only the two inner tree subsamples to determine possible effect of infiltration of emerging adults among treated and untreated trees, with the two outside trees acting as buffers. In both analyses, there were two treatments, four sampling times, and three reps available. The subsamples were gone after taking the means. A repeated measures analysis was used to account for possible correlations among sampling times.

The data were analyzed using PROC MIXED (SAS Institute, Inc. 2008), with "treatment," "time," and their interaction treated as fixed effects and "rep*treatment" as the random effect. Since the same trees were sampled four times, "time" was treated as a repeated measure and various variance-covariance error structures were fitted and the one with the lowest AICC value was used in the final analysis. The analyses were done using the mean number of insects collected per card because the number of cards was not consistent across trees or sampling time due to periodic blowdown of traps. The UNIVARIATE procedure was used to check the residuals for normality and for potential outliers before performing the final analysis.

\section{RESULTS AND DISCUSSION}

There was a significant interaction between treatment and time when all four subsamples were considered $(\mathrm{df}=1,12 ; \mathrm{F}=4.47$; $P=0.025)$ as well as when only the two inner trees were considered $(\mathrm{df}=1,12 ; \mathrm{F}=3.27 ; P=0.05)$. In the first week, $55 \%$ fewer weevils were trapped in the treated trees as compared to the untreated trees when all four subsamples were considered (Figure 1) and 60\% when only the two inner trees were considered $(P<0.05$ in both cases). After the first week, mean number of weevils trapped were similar among treated and untreated trees regardless if all four subsamples or only the inner trees were considered. Researchers presume that at this time most of the beetles would have emerged from the trees and the beetles being trapped were dispersing among the trees. Beetle numbers dropped after the third week so sampling was terminated.

The insect's emergence commences in early spring with males followed by females approximately one week later. Because the females aren't gravid when they emerge, they require time to feed, mate, and commence laying eggs (Booth unpublished observations 2010). By recognizing this, the study authors suggest that injections be applied in late summer or autumn to allow for delayed egg hatching ensuring that all larval stages are targeted.

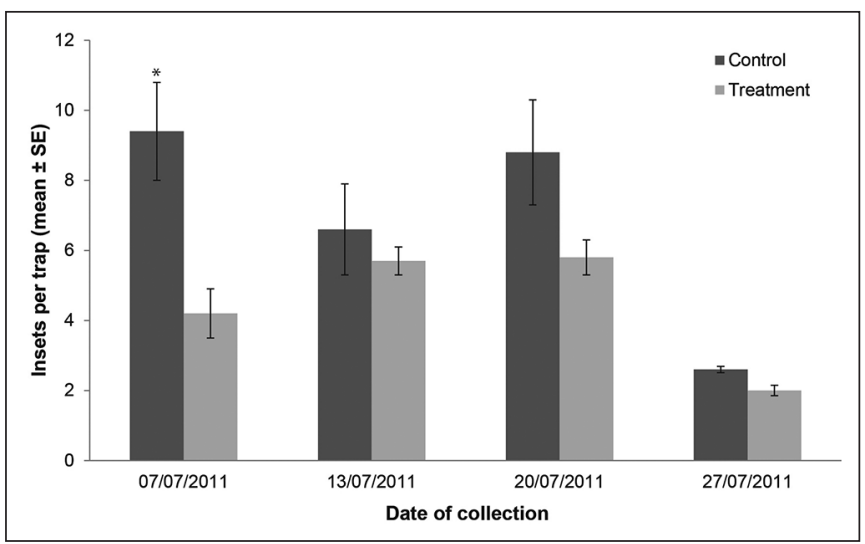

Figure 1. Mean trap count numbers of red elm bark weevils from treated and untreated American elm trees at Lethbridge, Alberta. Twelve trees were treated with TreeAzin Systemic Insecticide (5\% azadirachtin) at a rate of $16 \mathrm{ml}$ per $15 \mathrm{~cm}$ circumference using the Ecoject Microinjection System. Twelve trees acted as controls. Groups of four contiguous trees per replicate were alternated, creating three treatment groups and three control groups. Asterisk $\left(^{*}\right)$ denotes significant treatment effect $(P<0.05)$.

\section{CONCLUSION}

Late summer trunk injection with azadirachtin, using the Ecoject Microinjection System was shown to be effective in reducing red elm bark weevil emergence the following year in American elms. However, the treatments did not prevent infiltration of weevils from adjacent non-treated trees suggesting that all potential host trees in an area would need to be treated for adequate management of this pest.

Acknowledgments: Resources and personnel were provided by the Lethbridge Research Centre. We would like to thank Dr. R. Byers and Mr. D. Mullin for their assistance, and Mr. T. Entz for statistical analysis.

\section{LITERATURE CITED}

Booth, M., and D. Johnson. 2009. Pressurized-canister trunk injection of acephate, and changes in abundance of red elm bark weevil (Magdalis armicollis) on American elm (Ulmus americana). Arboriculture \& Urban Forestry 35(1):14-51.

Doccola, J., P.M. Wild, I. Ramasamay, P. Castillo, and C. Taylor. 2003. Efficacy of arborjet viper microinjections in the management of hemlock wooly adelgid. Journal of Arboriculture 29: 327-330.

Doughty, S.C., D.K. Pollet, R.J. Constantin, D.W. Wells, and K.L. Koonce. 1992. Paint-on application of acephate for aphid control on crape myrtle. Journal of Arboriculture 18:94-97. 
Helson, B., D. Thompson, G. Otis, N. Mckenzie, and J. Meating. 2007. TreeAzin, a systemic bioinsecticide containing azadirachtin for the control of an invasive woodboring beetle, the emerald ash borer. Poster 2007 Entomological Society of America Annual Meeting. December 9-12, 2007, San Diego, California, United States. Accessed 03/06/2012. <www.mauget.com/researchPDFs/canforestservice.pdf>

Marion, D.F., H. Larew, J.J. Knodel, and W. Natoli. 1990. Systemic activity of neem extract against the birch leaf miner. Journal of Arboriculture 16:12-16

SAS Institute Inc. 2008. SAS OnlineDoc 9.2. Cary, North Carolina, U.S.: SAS Institute Inc.

Saunders, C., M.D. Wartenbe, and W.B. Barr. 2004. Drought stress problems in Edmonton's Forest. 6th Canadian Urban forest Conference, Oct. 18-23, 2004. Kelowna, British Columbia. Accessed 03/06/2012. <www.treecanada.ca/cufc6/proceedings/papers/Saunders.pdf>

Michael Booth (corresponding author)

Lethbridge Research Centre

Agriculture \& Agri-Food Canada

Lethbridge, Alberta, Canada

TIJ $4 B 1$

boothm@agr.gc.ca

Mark S. Goettel

Lethbridge Research Centre

Agriculture \& Agri-Food Canada

Lethbridge, Alberta, Canada

T1J 4BI

bstedit@telusplanet.net
Résumé. L'injection dans le tronc d'ormes d'Amérique (Ulmus americana) de azadirachtin au moyen du Système d'Injection Ecoject ${ }^{\mathrm{TM}}$ afin de diminuer l'émergence du charançon de l'orme (Magdalis armicollis) a été évaluée. Douze arbres matures ont été injectés avec le TreeAzin ${ }^{\mathrm{TM}}$ au début de août 2010 à un taux de $16 \mathrm{ml}$ par $15,2 \mathrm{~cm}$ de circonférence de tronc mesuré au DHP. L'année suivante, l'activité des charançons a été suivie à intervalle hebdomadaire durant quatre semaines au moyen de pièges collants disposés dans la couronne. Il y a eu une diminution significative de 55 à $60 \%$ de l'activité des charançons au début de l'été chez les arbres traités comparativement aux arbres-témoins ce qui suggérait que cette méthode peut être un outil efficace pour la gestion de ce parasite.

Zusammenfassung. Hier wurde die Stamminjektion von Azadirachtin in Ulmen (Ulmus americana) mithilfe des Ecoject ${ }^{\mathrm{TM}}$ Microinjection Systems zur Begrenzung der Schlupfzahlen des Roten Ulmen-borkenkäfers (Magdalis armicollis) bewertet. Zwölf ausgewachsene Bäume wurden jeder im frühen August 2010 in einer Rate von $16 \mathrm{ml}$ pro 15,2 cm Stammumfang in Brusthöhe mit TreeAzin ${ }^{\mathrm{TM}}$ injiziert. Im folgenden Jahr wurde die Aktivität der Käfer in wöchentlichen Intervallen für vier Wochen mit Klebetafeln in der Krone überwacht. Es gab einen signifikanten Rückgang um 55-60 \% bei der Aktivität der Käfer im Frühsommer bei den behandelten Bäumen im Vergleich zu Kontrolle, was bedeutet, dass diese Methode ein effektives Werkzeug zur Kontrolle dieses Schädlings sein kann

Resumen. Se evaluó la inyección al tronco de azaridachtin en árboles de olmo (Ulmus americana) usando el sistema de microinyección Ecoject ${ }^{\mathrm{TM}}$ para reducir el número de emergencia de barrenadores (Magdalis armicollis). Se inyectaron doce árboles maduros con TreeAzin ${ }^{\mathrm{TM}}$ a principios de Agosto de 2010 a una tasa de $16 \mathrm{ml}$ por cada $15.2 \mathrm{~cm}$ de circunferencia del tronco a la altura del pecho. En el siguiente año la actividad del insecto fue monitoreada a intervalos semanales por cuatro semanas usando trampas pegajosas localizadas en la copa. Hubo una reducción significativa de 55\%-60\% en la actividad del insecto en el verano temprano en los árboles tratados, comparados con los controles, sugiriendo que este método puede ser una importante herramienta de manejo para esta plaga. 